\title{
NEW SPECIES FOR THE FLORA OF THE REPUBLIC OF MACEDONIA
}

\author{
Vlado Matevski \\ Macedonian Academy of Sciences and Arts, 1000 Skopje, Republic of Macedonia \\ vlado.matevski@yahoo.com
}

\begin{abstract}
During floristical investigation in northen, eastern and north-eastern parts of the Republic of Macedonia four taxa of vascular plants were found which were not previously reported for the country - Andrachne telephioides L., Chorispora tenella (Pallas) DC., Nepeta parviflora M. Bieb. and Marrubium pestalozzae Boiss. The genus Andrach$n e$ and genus Chorispora are new genera for the territory of the Republic of Macedonia.
\end{abstract}

Kew words: flora; Macedonia; distribution; Andrachne telephioides L.; Chorispora tenella (Pallas) DC.; Nepeta parviflora M. Bieb.; Marrubium pestalozzae Boiss

\section{INTRODUCTION}

Floristic researches continually carried out on the territory of the Republic of Macedonia keep supplementing current data by adding new information concerning genera and species belonging to previously published families in the edition "Flora of the Republic of Macedonia", as well as families that are yet to be published in the future volumes of this edition. This paper mentions the first data regarding distribution of 4 new species on the territory of the Republic of Macedonia, which had been discovered in the past period - Andrachne telephioides L. (Euphorbiaceae, Phyllanthaceae), Chorispora tenella (Pallas) DC. (Brassicaceae), Nepeta parviflora M. Bieb. (Lamiaceae) and Marrubium pestalozzae Boiss. (Lamiaceae).

\section{EXPERIMENTAL SECTION}

Floristic researches were carried out in the northern, eastern and south-eastern parts of the territory of the Republic of Macedonia (Skopje, the surroundings of Štip, Ovče Pole and the surroundings of Kriva Palanka). Herbarium material is deposed in the Herbarium of the Institute of Biology, Faculty of Natural Sciences and Mathematics in
Skopje (MKNH). When determining the herbarium material, appropriate literature was consulted (Prodromus Florae peninsulae Balcanicae, I-II [1, 2]; Flora Europaea, I-III [3]; Flora of the Republic of Macedonia, 1(3-4) $[4,5]$ and other regional floras), as well as some special papers and databases (Euro+Med Plant Base [6]) dealing with taxonomy, nomenclature and chorology of the taxa studied.

\section{RESULTS AND DISCUSSION}

\section{Andrachne telephioides $\mathbf{L}$.}

Mk Štip: Isar, along the walkway to the top of the hill, $350 \mathrm{~m}, 15.06 .2013$ (leg. et det. V. Matevski) $(\mathrm{MKNH})$

Distribution range of the species Andrachne telephioides covers the territory of the Mediterranean, South-East Europe, Caucasus, Southern, SouthWestern and as far as Central Asia and East Africa. As far as European areas are concerned, this species is distributed in dry, arid and semi-arid regions of Bulgaria, Crete, Greece, Spain, Italy, France, parts of Former Yugoslavia, Crimea, Ukraine (Tutin [7]; Euro+Med Plant Base [6]).

On the territory of the Republic of Macedonia, Andrachne telephioides was first found in the 
surroundings of Štip (Figure 1), in one of the aridest regions on the territory of the Republic of Macedonia. It grows on trampled places, near the paved paths leading towards the Fortress of Isar which rises above the Bregalnica river. This river is a kind of a corridor via which modified SubMediterranean climate reaches the eastern parts of Macedonia (across Ovče Pole, Štip ravine, as far as Kočani-Vinica ravine). At the same time, this river is a significant phyto-geographic corridor for a great number of Mediterranean, particularly EastMediterranean and Sub-Mediterranean plants (Astragalus sinaicus, Buglossoides sibthorpiana,
Cachrys cristata, Centaurium spicatum, Echinophora sibthorpiana, Ephedra major, Hypericum annulatum, Malvella sherardiana, Onobrychis pindicola, Pistacia terebinthus, Saxifraga graeca, Sideritis lanata, Silene scorpilii, Trifolium stellatum and others), thus contributing considerably to expanding their range of distribution in these regions.

This species was not registered when studying the family Euphorbiaceae in the edition Flora of the Republic of Macedonia (Micevski [5])

This genus and species is new for the flora of the Republic of Macedonia.

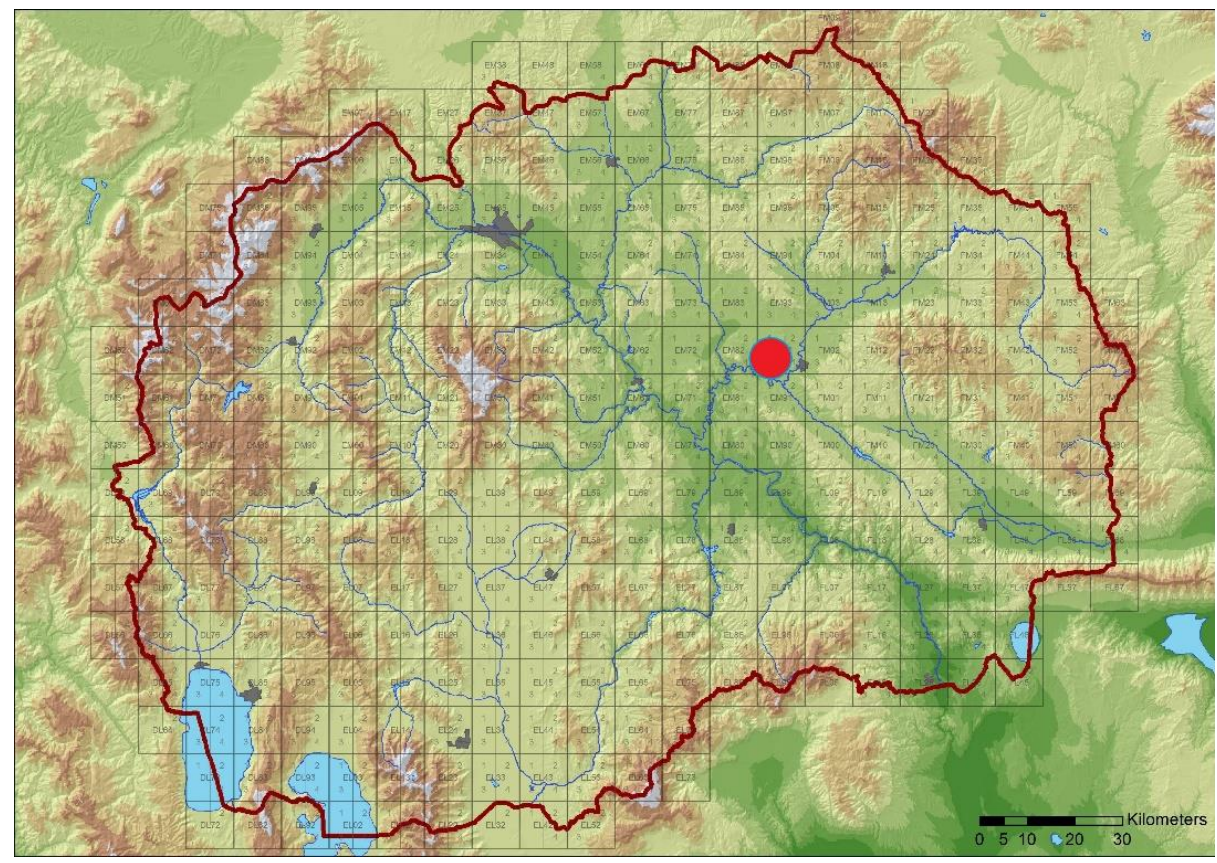

Figure 1. Andrachne telephioides - Map of distribution in the Republic of Macedonia

\section{Chorispora tenella (Pallas) DC.}

Mk Skopje-railway station Madžari, alongside the railway line, $210 \mathrm{~m}, 17.04 .1999$ (leg. et det. V. Matevski) (MKNH)

According to Atlas Florae Europeae (Jalas et al. [8]), Kästner [9] and Euro+Med Plant Base [6], natural range of distribution of Chorispora tenella stretches from the steppes in Southern Russia (as far as Siberia) to Slovenia, Serbia - Vojvodina, Croatia, Slovakia, Romania, Bulgaria, Moldova, Crimea, Ukraine, and Trans-Caucasus region (Azerbaijan, Armenia, Georgia). In many parts of Central Europe this plant grows as weed in land farmed with grain crops, and as introduced plant (neophyte) it has been registered in Austria, Ger- many, Belorussia, the Czech Republic, Estonia, Finland, Latvia, Lithuania, Slovakia, Greece.

As to the territory of the Republic of Macedonia, this plant has been registered on one locality only, in the outskirts of the city of Skopje, nearby the railways in the vicinity of the railway station in Madžari (Figure 2). Relevant books state that possible habitats of this species - Chorispora tenella might be places where grain crops are being unloaded either from railway freight cars or from ships. Having in mind the location this species had been registered at (nearby railway tracks, in the vicinity of a railway station), we could easily assume that on the territory of the Republic of Macedonia it is also an introduced species, which uses railway transportation as a means of expanding its range of distribution. 


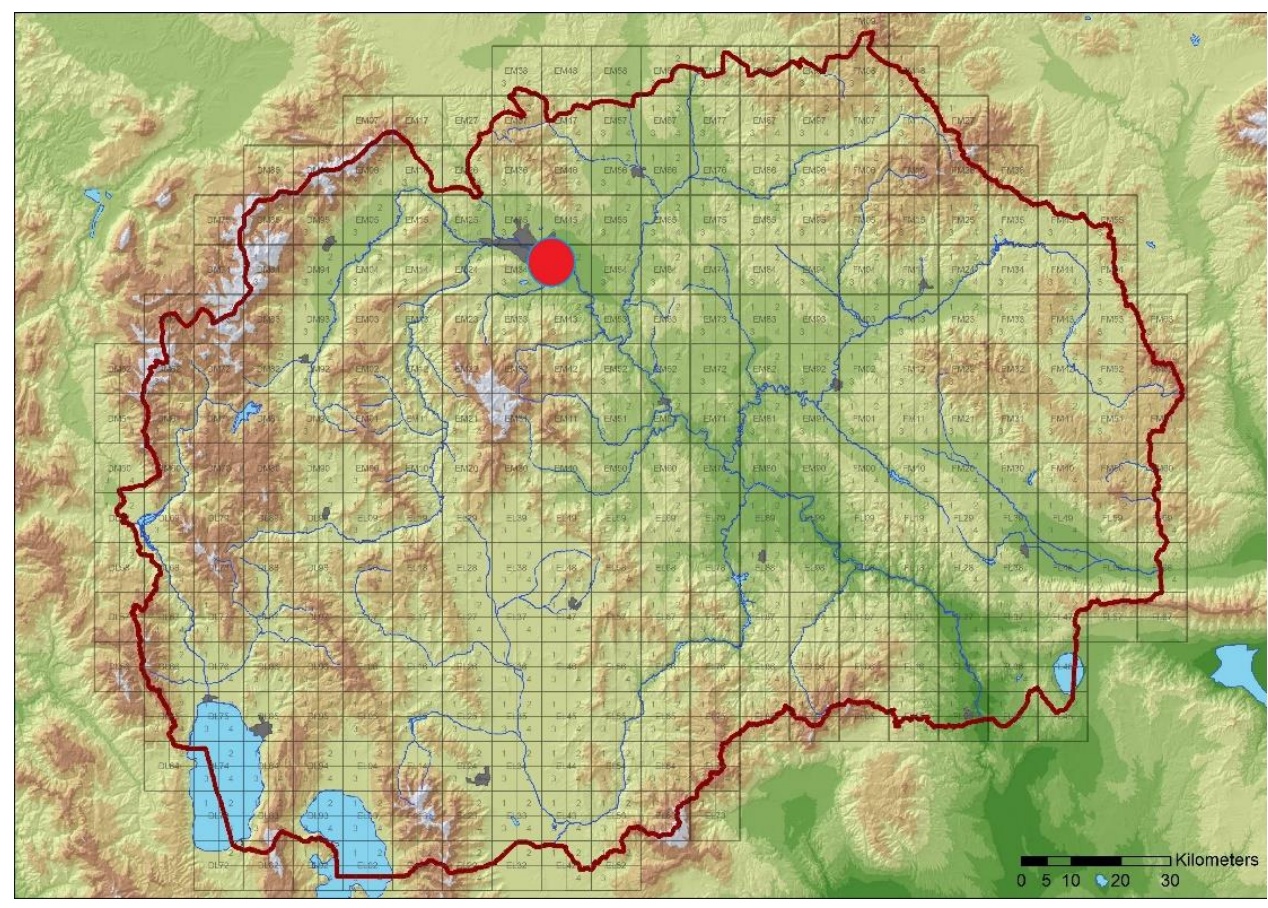

Figure 2. Chorispora tenella - Map of distribution in the Republic of Macedonia

This species was not registered when studying the Brassicaceae family in the edition Flora of the Republic of Macedonia (Micevski [4]).

This genus and species is new for the flora of the Republic of Macedonia.

\section{Nepeta parviflora M. Bieb (=Nepeta ucranica $L$. subsp. parviflora (M. Bieb.) M. Masclans de Bolos)}

Mk Ovče Pole - between Vrsakovo village and Sudič village, 41.838445433516895 N, 22.138 16716877755 E, 23.05.2015 (leg. et det. V. Matevski) (MKNH)

Nepeta parviflora is a plant species spread in South-Eastern Europe - Bulgaria, Romania, Ukraine, Crimea, Southern Russia (Turner [10], Euro+Med Plant Base [6]). According to the report of the Ministry of Environment of Hungary [11], western border of distribution of this species is considered to be on the territory of Hungary, where it used to be considered disappeared for a long time, but has recently been registered on the territory of this country.

On the territory of the Republic of Macedonia, this species is with quite limited distribution. It has been registered on one locality only, in the aridest, steppe-like region of Macedonia, in Ovče Pole, between the villages of Vrsakovo and Sudič (Figure 3). Most of the areas where this species thrives have been turned into farmland, whereas only on small patches, mainly on the higher surrounding hills, there are still preserved fragments with steppe-like vegetation. It is exactly this type of location, predominated by paleogenic and neogenic marl grounds, where this population develops, with a host of steppe and endemic species thriving in such regions, some of which being Anchusa italica, Anchusa macedonica, Astragalus parnassi, Centaurea finazzeri, Convolvulus holosericeus, Echinophora sibthorpiana, Ferulago macedonica, Phlomis herba-venti subsp. pungens, Salvia aethiopsis, Salvia jurisicii, Stipa bromoides, Ziziphora capitata, etc.

Regarding the taxonomic status of Nepeta parviflora, it is still subject of additional studies, taking into consideration its high similarity to the species Nepeta ucranica. In Euro+Med Plant Base [6], it is added as subspecies to the species Nepeta ucranica L. (Nepeta ucranica subsp. parviflora (M. Bieb.) M. Masclans de Bolos). Still, despite the fact that there is similarity of this better taxon to the species Nepeta ucranica, the prevailing opinion is that Nepeta parviflora should be considered as a indipendent species (Turner [10]). This view is supported by the studies of Pădure [12], related to the morpho-anatomic features of the flowers and inflorescens of the the species belonging to genus Nepeta on the territory of Romania. 


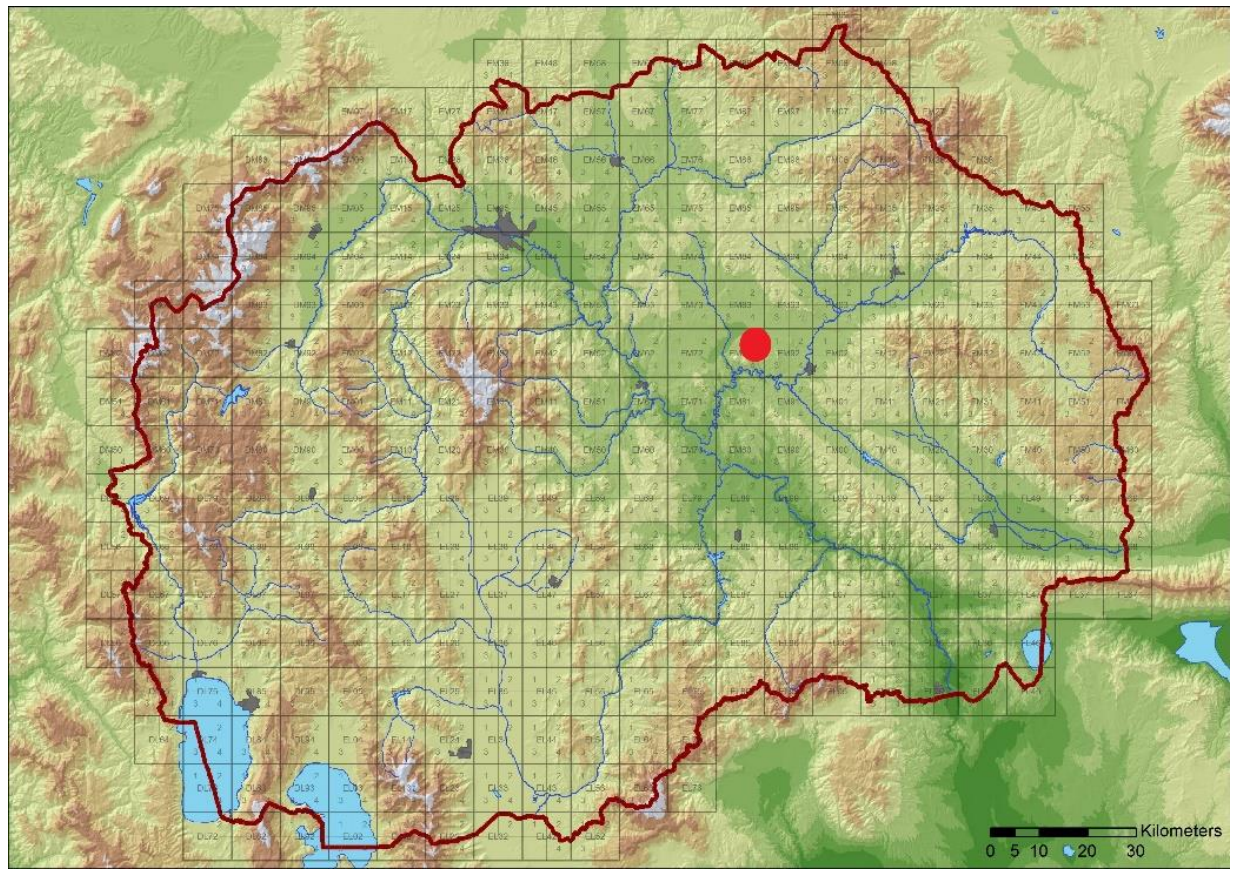

Figure 3. Nepeta parviflora - Map of distribution in the Republic of Macedonia

\section{Marrubium pestalozzae Boiss.}

Mk Kriva Palanka - Psača village, on ruderal site, $42^{\circ} 10^{\prime} 11^{\prime \prime} \mathrm{N}, 22^{\circ} 12^{\prime} 18^{\prime \prime} \mathrm{E} ; 514 \mathrm{~m}, 5.10 .2006$ (leg. et det. V. Matevski) (MKNH)

Taxonomic status and position of the taxon Marrubium pestalozzae is still deemed problematic and unclearly determined. Accordingly, there is a variety of opinions with reference to its taxonomic value. In the editions Flora Europaea [13] and Euro+Med Plant Base [6], its taxonomic status is clearly support its consideration as independent species, whereas in Flora of Bulgaria [14] it is considered as a synonym of the species Marrubium parviflorum $\mathrm{L}$.

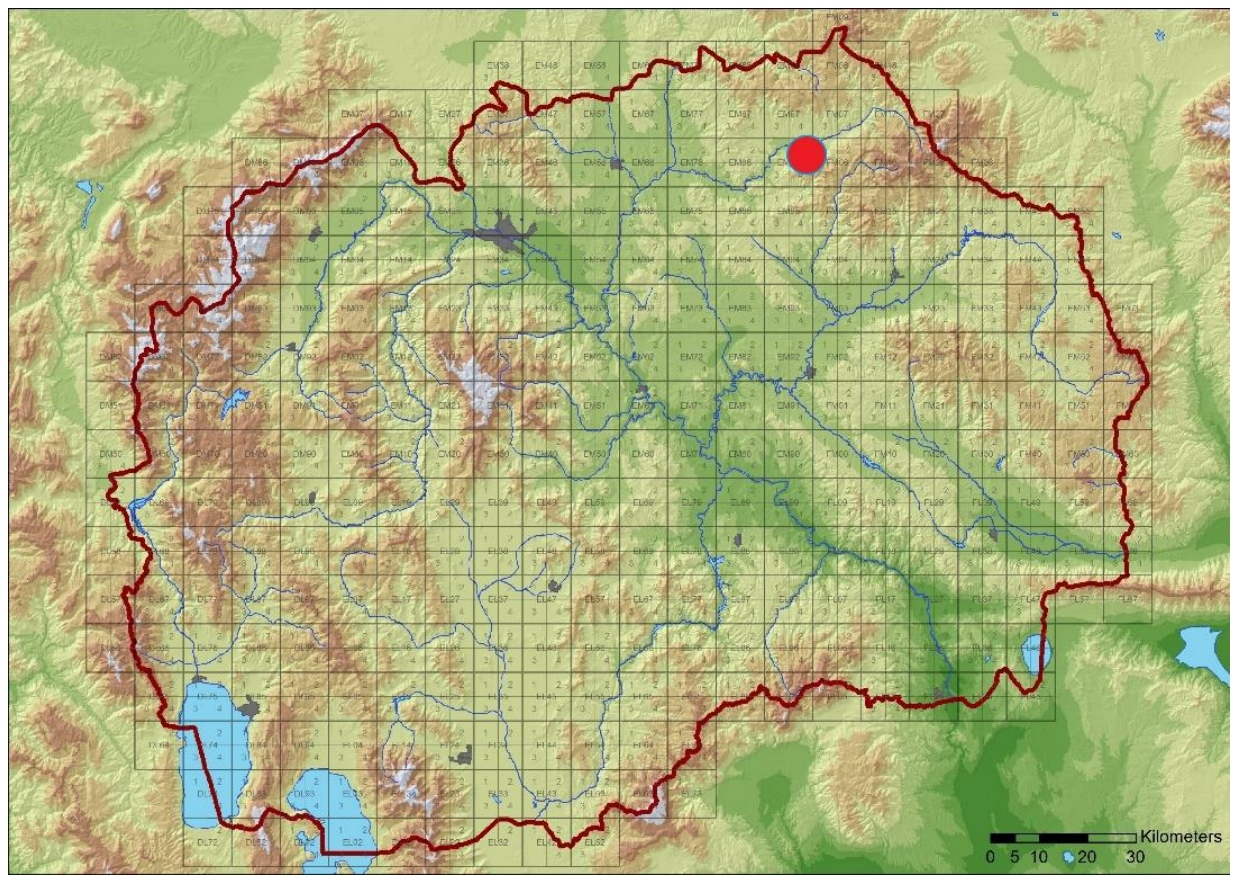

Figure 4. Marrubium pestalozzae - Map of distribution in the Republic of Macedonia 
In Euro+Med Plant Base [6], where both species - Marrubium pestalozzae and Marrubium parviflorum - are listed, there is a note that these two species are strongly likely to be one taxon ("perhaps identical with $M$. parviflorum"). Differentiation between these two species is made based on slight morphological differences concerning the number, size and position of the calyx teeth. Analysis of the herbarium material from the territory of the Republic of Macedonia (the surroundings of Kriva Palanka) has shown that this species is more likely consistent with the diagnostic description of Marrubium pestalozzae.

According to the map of range of distribution presented in Euro+Med Plant Base [6], the range of distribution of Marrubium pestalozze covers the territories of Bulgaria, Greece, Ukraine, Crimea and central and southern parts of European part of Russia, whereas the range of distribution of Marrubium parviflorum stretches on the territories of Turkey and trans-Caucasus region (Azerbaijan, Armenia and Georgia).

The species Marrubium pestalozzae has been registered in northern-eastern parts of the territory of the Republic of Macedonia, in the surroundings of Kriva Palanka, the village of Psacha. It grows in ruderal habitats, in the centre of the settlement, alongside the asphalt road Kumanovo-Kriva Palanka (Figure 4).

Acknowledgement. The investigation was supported by the project fund of the Macedonian Academy of Sciences and Arts.

\section{REFERENCES}

[1] A. Hayek, Prodromus Florae Peninsulae Balcanicae, I. Feddes Repert., Beih., 30 (1924-1927), Dahlem bei Berlin.
[2] A. Hayek, Prodromus Florae Peninsulae Balcanicae, II. Feddes Repert., Beih., 30 (1928-1931), Dahlem bei Berlin.

[3] T. G. Tutin et al., Flora Europaeae, I-III. (19641972), Cambridge.

[4] K. Micevski, Flora na Republika Makedonija. MANU, Skopje, 1(3) (1995), pp. 401-772.

[5] K. Micevski, Flora na Republika Makedonija. MANU, Skopje, 1(4) (1998), pp. 781-1113.

[6] Euro+Med Plant Base http://ww2.bgbm.org/EuroPlusMed/query.asp

[7] T. G. Tutin, Andrachne L. In T.G. Tutin et al. (eds.) Flora Europaeae, 2 (1968) p. 211, Cambridge.

[8] J. Jalas, J. Suominen, R. Lampinen, Atlas Florae Europaeae. Distribution of Vascular Plants in Europe, 11. Cruciferae (Ricotia to Raphanus). Comm. Map. Fl. Europe \& Soc. Biol. Fennica Vanamo, (1996), Helsinki.

[9] A. Kästner, Chorispora tenella (PALL.) DC., Brassicaceae, ein Neubürger in der Flora von Sachsen-Anhalt. Mitt. florist. Kart. SachsenAnhalt, 15 (2010), Halle, pp. 55-58

[10] C. Turner, Nepeta L. in Tutin, T.G. et al. (eds) Flora Europaea, 3 (1972), pp. 158-160, Cambridge.

[11] Summary - In Ministry of Environment Conservation Office: Conservation Plans: Raggedy Conservation Office. 2004, p. 4 (pdf) Access Time: June 14, 2014

[12] I. M. Pădure, Morpho-Anatomy of Flower and Inflorescence in Nepeta L. (Lamiaceae, Nepetoideae). Analele ştiinţifice ale Universităţii "Al. I. Cuza" Iaşi, Tomul LII, s. II a. Biologie vegetală (2006).

[13] J. Cullen, Marrubium L. in Tutin, T. G. et al., (eds) Flora Europaea, 3 (1972), pp. 137-138, Cambridge.

[14] D. Peev, 1989. Marrubium L., in Flora of Bulgaria, BAN, 9 (1989), pp. 365-369, Sofia.

\section{НОВИ ВИДОВИ ЗА ФЛОРАТА НА РЕПУБЛИКА МАКЕДОНИЈА}

\section{Владо Матевски}

Македонска академија на науките и уметностите, 1000 Скопје, Република Македонија

За време на флористичките истражувања во северните, источните и северо-источните делови на Република Македонија беа откриени 4 видови васкуларни растенија, кои претходно не беа регистрирани на нејзината територија - Andrachne telephioides L., Chorispora tenella (Pallas) DC., Nepeta parviflora M. Bieb. и Marrubium pestalozzae Boiss. Истовремено, родовите Andrachne и Chorispora претставуваат нови родови за територијата на Република Македонија.

Клучни зборови: флора, Македонија, распространување, Andrachne telephioides L., Chorispora tenella (Pallas) DC, Nepeta parviflora M. Bieb., Marrubium pestalozzae Boiss. 
